\title{
THE USE OF VIRTUAL LABORATORY WORKS IN THE STUDY OF ENGINEERING DISCIPLINES OF OIL AND GAS TRAINING
}

\section{ИСПОЛЬЗОВАНИЕ ВИРТУАЛЬНЫХ ЛАБОРАТОРНЫХ РАБОТ ПРИ ИЗУЧЕНИИ ТЕХНИЧЕСКИХ ДИСЦИПЛИН НЕФТЕГАЗОВОГО НАПРАВЛЕНИЯ ОБУЧЕНИЯ}

\author{
SYZRANTSEV, Vladimir N. ${ }^{1}$; CHELOMBITKO, Sergey I. ${ }^{1 *}$; GAMMER, Maxim D. ${ }^{2}$ \\ ${ }^{1}$ Tyumen Industrial University, Department of Machines and Equipment of Oil and Gas Industry \\ 70 Melnikaite Street, ZIP code 625027, Tyumen - Russian Federation \\ (phone: +73452283013 ) \\ ${ }^{2} \mathrm{OOO}$ NPF Infotech, 3650 years of October Str., zip code 625027, Tyumen - Russian Federation \\ (phone: +79199510073 ) \\ * Corresponding author \\ e-mail: gammermax@yandex.ru
}

Received 01 December 2017; received in revised form 09 February 2018; accepted 15 May 2018

\section{RESUMO}

O efeito da introdução de uma forma interativa de aprendizagem no estudo de disciplinas de engenharia é examinado, bem como fatores que diminuem a eficácia dos resultados da utilização de modernos auxiliares de treinamento em informática (simuladores). São descritos trabalhos de laboratório virtual que são usados no departamento "Máquinas e equipamento da indústria de óleo e gás" da Universidade Industrial de Tyumen em estudar engenharia geral e disciplinas especiais da área "Engenharia de óleo e gás", perfil "Operação e manutenção de instalações tecnológicas de produção de petróleo e gás ". Com base na experiência do uso de simuladores no departamento, concluiu-se que o maior efeito de alcançar os conhecimentos, habilidades e habilidades requeridos foi obtido usando simuladores na forma de trabalhos virtuais de laboratório.

Palavras-chave: trabalhos virtuais de laboratório, simuladores, equipamentos de petróleo e gás.

\begin{abstract}
The effect from the introduction of an interactive form of learning in the study of engineering disciplines is examined, as well as factors that decrease the effectiveness of the results of using modern computer training aids (simulators). Virtual laboratory works are described that are used at the department "Machines and equipment of the oil and gas industry" of the Industrial University of Tyumen in studying general engineering and special disciplines of the area "Oil and gas engineering", profile "Operation and maintenance of technological facilities of oil and gas production". Based on the experience of using simulators at the department, it was concluded that the greatest effect of achieving the required knowledge, abilities, and skills was obtained by using simulators in the form of virtual laboratory works.
\end{abstract}

Keywords: virtual laboratory works, simulators, oil and gas equipment.

\section{АННОТАЦИЯ}

Рассматривается влияние внедрения интерактивной формы обучения в изучение инженерных дисциплин, а также факторы, снижающие эффективность результатов использования современных средств компьютерного обучения (тренажеров). Описаны виртуальные лабораторные работы, которые 
используются на кафедре «Машины и оборудование нефтегазовой промышленности» Тюменского индустриального университета при изучении общих инженерных и специальных дисциплин области «Нефтегазовая техника», профиль «Эксплуатация и техническое обслуживание» технологических установок добычи нефти и газа». Основываясь на опыте использования тренажеров на кафедре, был сделан вывод, что наибольший эффект от достижения необходимых знаний, умений и навыков был получен с помощью тренажеров в виде виртуальных лабораторных работ.

Ключевые слова:виртуальные лабораторные работы, тренажеры, нефтегазовое оборудование.

\section{INTRODUCTION}

Current federal state educational standards of the third generation for technical specialties require that at least $10 \%$ of the time of studying the disciplines is carried out using an interactive form of training.

The introduction of modern computer training tools allows:

- improving the quality of student training;

- reducing training costs;

- reducing the time required to master disciplines with increasing numbers of trainees;

- reducing the risk during experimental studies;

- increasing the efficiency of labor protection, industrial and environmental safety;

- conducting experiments within the limited time (during the period), the actual duration of which would range from several days to several months;

- investigating the processes, the possibility of implementing them according to the requirements of safety provisions in a university environment is either limited or impossible at all.

The complex study of the developed modern computer training aids, computer-based simulators, performed in (Gammer et al., 2011), showed that factors that reduce the effectiveness of the results of their application are:

- the direction of the developed "industry" computer simulators, as a result of which many types of computer-based simulators used in the educational process are left out;

- there is no classification of simulators (by the goals, composition, nature of the trainee's activity, subject of training and way of implementation);

- there is no developed methodology for assessing the effectiveness of the use of simulators taking into account the factor of "successful" implementation in the educational process;
- there is no systematization of user requirements and evaluation criteria for computer-based simulators (adequacy of the mathematical model, quality of synthesis of graphics, sound, interaction, etc.);

- the inconsistency of the interfaces of the interaction of existing computer-based simulators with each other, which makes it difficult to integrate and further share them;

- to create computer-based simulators, a universal system of their computer-aided design is needed.

\section{MATERIALS AND METHODS}

Considering the systematization of user requirements (Gammer et al., 2011), the proposed criteria for the effectiveness of simulators, the solved questions of determining and justifying the composition of imitators, the methods for implementing their constituent elements and the developed technologies for creating simulators (Kolesov et al., 2009; Cherezov et al., 2010; Gammer and Kolesnikov, 2012; Gammer and Golofast, 2013; Gammer et al., 2009; Gammer et al., 2012; Cherezov, 2010; Cherezov and Syzrantsev, 2010; Cherezov, 2011), at the department "Machines and equipment of oil and gas industry", Industrial University of Tyumen, a set of virtual laboratory works was developed, used for a number of years in the process of teaching general technical and special disciplines of the field "Oil and gas engineering", the profile "Operation and maintenance of technological facilities of oil and gas production".

\section{RESULTS AND DISCUSSION:}

Simulators can be used at almost all stages of the educational process.

In the course of lectures, the use of simulators allows creating an overview of a topic or a problem, systematizing and generalizing 
knowledge on a topic. At the same time, when lecturing the material, students, as a rule, do not have the opportunity to take the initiative. The use of simulators in the process of performing laboratory works provides knowledge on the basis of obtaining and processing experimental data, quantitative characteristics of real physical quantities that determine the behavior of the objects under investigation that confirm or disprove the formulated objective functions of the experiment. Realization with the help of simulators, virtual laboratory works (VLW) and learning physical experiments, allows working out the basic techniques and technologies for planning and conducting the experiment, including its main stages: definition of the purpose and objectives of the research, methods and technologies of achieving the goal, equipment and technologies used. With the course design projects, the use of simulators makes it possible to apply the knowledge gained when solving complex problems related to the sphere of activity of future specialists. Simulators are an effective tool for assessing the skills and professional abilities of students in their attestation. During the implementation of practical exercises, simulators provide an opportunity to study special equipment, the principles of its operation, assembly, adjustment, characteristic of the profession being mastered. An important direction in using simulators is their inclusion in the independent work of students, which allows for a much broader study of the discipline, often severely limited by the volume of lectures, laboratory and practical exercises prescribed in the curriculum (Gubsky, 2009; Palyukh et al., 2012; Trukhin, 2005; Solovov and Menshikova, 2015; Solovov and Menshikova, 2012; Solovov, 1996; Trukhin, 2008; Skripka and Trukhin, 2005; Trukhin, 2007).

Let us consider examples of the developed virtual laboratory works for general technical and special disciplines, read at the department.

The most important characteristic of the strength of a material under conditions of its cyclic deformation used to determine the longevity of parts is the fatigue curve. The construction of this curve requires several months of testing the samples for durability. The developed VLW (Figure 1) makes it possible to realize the entire testing process during one study period by introducing an acceleration coefficient (without losing the physics of the accumulation of damage). Investigations are carried out for a number of materials, while the roughness of the samples and their geometric characteristics and the hardness of the material are varied (according to the teacher's instructions), the possibility of testing at low temperatures is provided.

The tests of samples shown in Figure 1 are performed under bending conditions with rotation. Another version of the test under conditions of cyclic tension-compression of the samples is shown in Figure 2.

To study the operation and characteristics of various pumps used in the oil and gas industry, a VLW complex was developed, shown in Figure 3 , identical to the bench equipment installed in the specialized laboratory "Hydraulic machines and compressors".

The developed complex allows performing the following works:

(rating);

- testing a centrifugal pump D 200-36b

- testing a centrifugal pump D 200-36b (cavitation testing);

- testing a centrifugal pump CNS 180-950 (rating);

- testing a centrifugal pump CNS 180-950 (cavitation testing);

- testing a piston pump ANT-150 (rating);

- test a positive displacement motor DT105 (with ANT-150);

- testing a piston pump UBN-600 (rating).

To obtain knowledge about compressor operation, compressor start-up skills (the procedure assumes consecutive execution of more than forty operations with mandatory monitoring of instrument readings), a VLW was developed, the screenshot of which is shown in Figure 4.

To study the work and kinematics of a beam-pumping unit for practical and laboratory studies, a VLW was developed, a screenshot of which is shown in Figure 5.

\section{CONCLUSIONS:}

Based on the experience of using simulators in the study of the academic disciplines of the department "Machines and equipment of the oil and gas industry" it was concluded that the greatest effect of achieving the required knowledge, skills and habits was obtained by using simulators in the form of virtual 
laboratory works.

\section{REFERENCES:}

1. Cherezov, K. M.; Gammer, M. D. Scho. Technol., 2010, 4, 140-146.

2. Cherezov, K. M. News of High. Edu. Institut. Oil and Gas, 2010, 3, 101-105.

3. Cherezov, K. M. News of High. Edu. Institut. Oil and Gas, 2011, 2, 127-129.

4. Cherezov, K. M.; Syzrantsev, V. N. News of High. Edu. Institut. Oil and Gas., 2010, 4, 4045.

5. Gammer, M. D.; Gilmanov, Yu. A.; Kolesov, V. I.; Kurylev, E. V. Open Edu., 2009, 5, 4852.

6. Gammer, M. D.; Golofast, S. L. News of High. Edu. Institut. Oil and Gas., 2013, 2, 119-124.

7. Gammer, M. D.; Kolesnikov, S. A. Proceed. of the Gubkin State Univer. of Oil and Gas., 2012, 4, 119-130.

8. Gammer, M. D.; Kolesnikov, S. P.; Kolesov, G. V. Casting and Metallurgy, 2012, 3, 320324.

9. Gammer, M. D.; Syzrantsev, V. N.; Golofast, S.L. Computer-based simulators in technical education, Novosibirsk: "Nauka", Siberian Publishing Company of the Russian Academy of Sciences, 2011.

10. Gubsky, Ye. G. Modern Probl. of Sci. and Edu., 2009, 1, 55.

11. Knyazeva, E. M. Fundamental research, 2012, 6, 587-591.

12. Kolesov, V. I.; Kuzyakov, O. N.; Gammer, M. D.; Kurylev, E. V.; Gilmanov, Yu. A. News of High. Edu. Institut. Oil and Gas., 2009, 3, 103-108.

13. Palyukh, B. V.; Tvardovsky, A. V.; Ivanov, V. K. Qual. of Edu., 2012, 10, 34-37.

14. Skripka, V. I.; Trukhin, A.V.; Open and Distan. Edu., 2005, 1, 11.

15. Solovov, A. V. Informatics and Edu., 1996, 1 , 13-19.

16. Solovov, A. V.; Menshikova, A. High. Edu. in Rus.,2015, 11, 66-75.

17. Solovov, A. V.; Menshikova, A. Open and Distan. Edu., 2012, 4, 80-85.

18. Solovov, A. V.; Menshikova, A. Remote and Virt. Edu., 2015, 12, 64-73.

19. Trukhin, A. V. Inform. Technolog. in High. Edu., 2005, 58-67.
20. Trukhin, A. V. Open and Distan. Edu., 2007, 3, 47-55.

21. Trukhin, A. V. Open and Distan. Edu., 2008, 1, 32-39. 


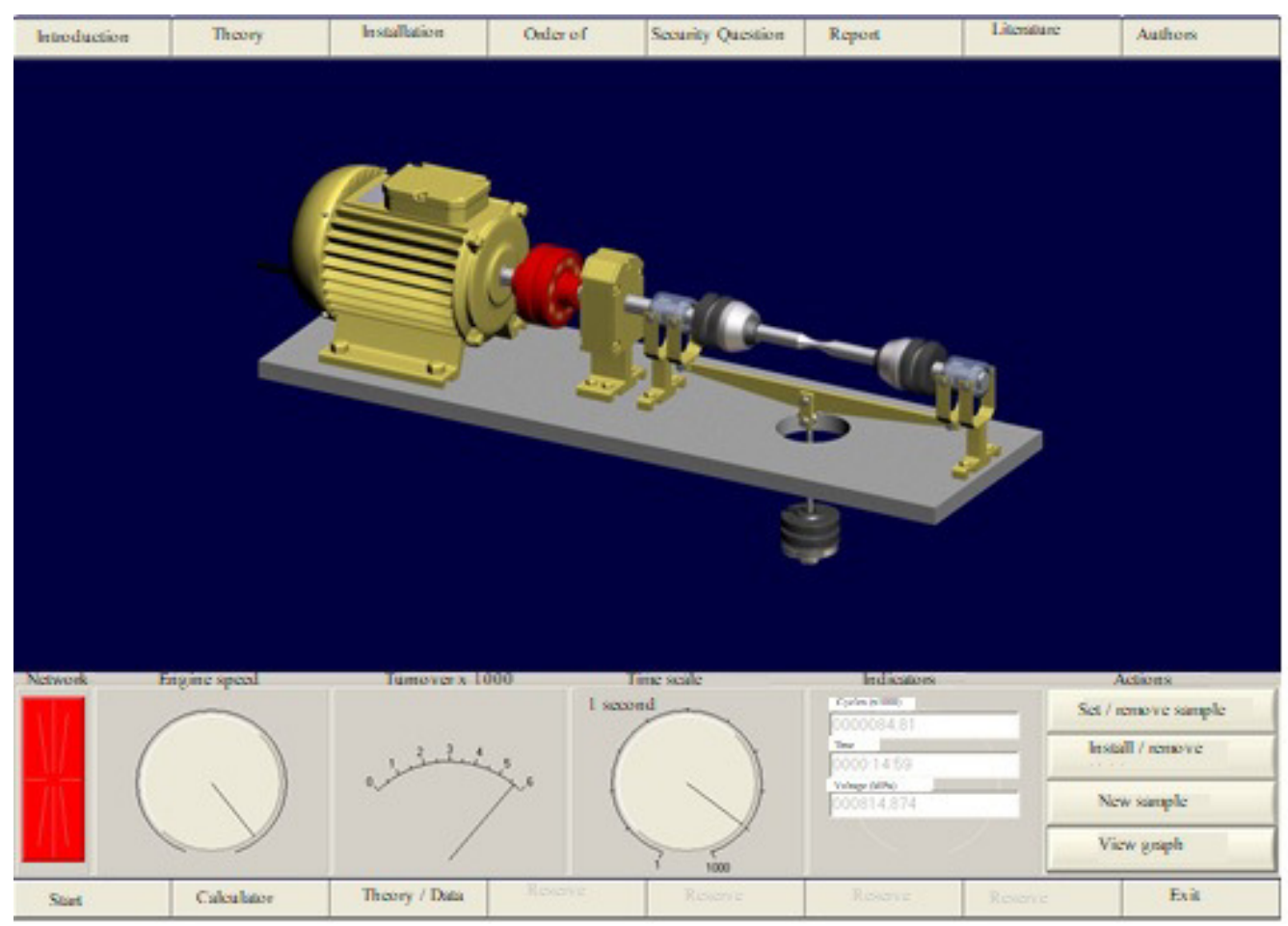

a)

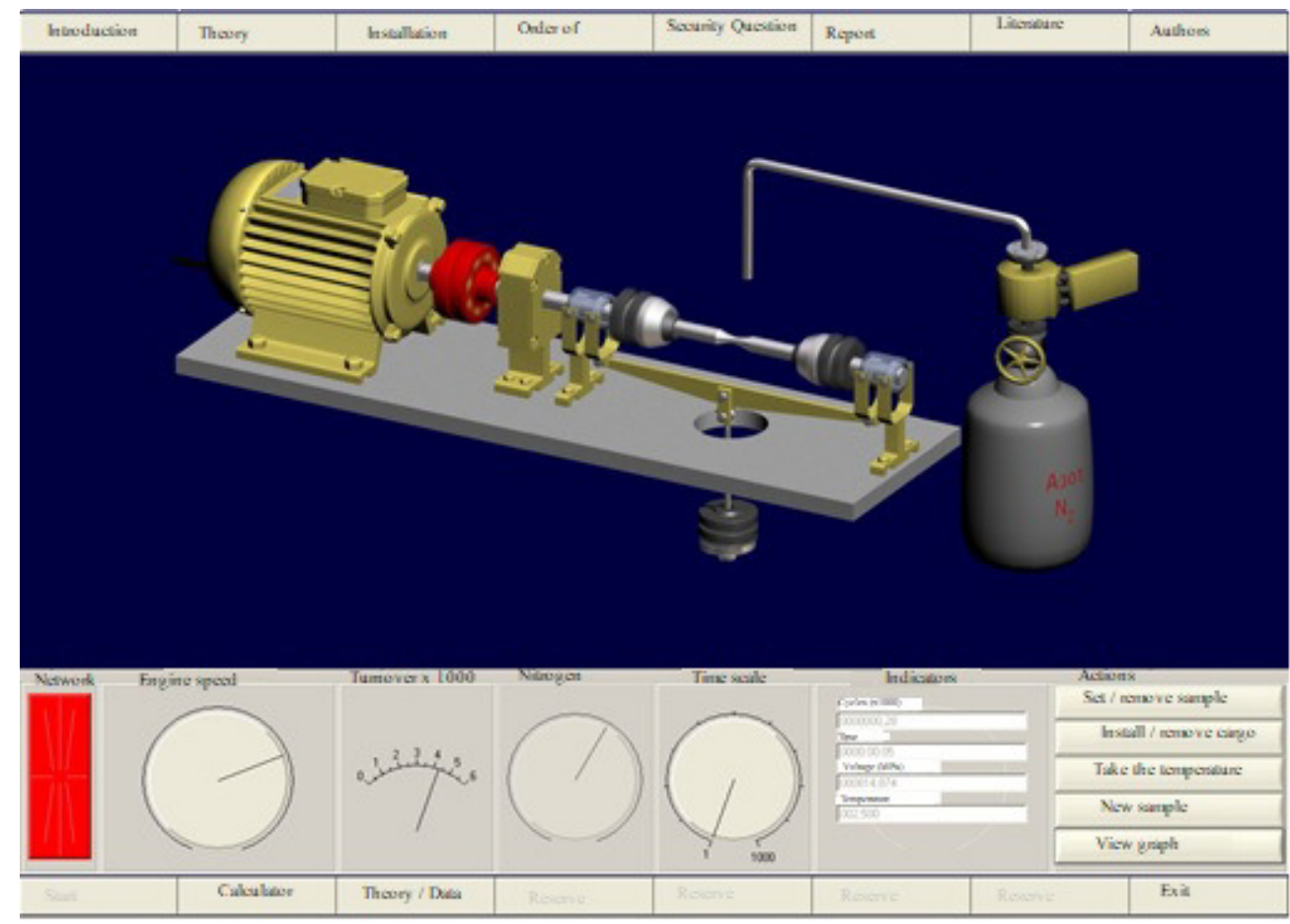

b)

Figure 1. Testing of samples for durability: a) at normal temperature, b) at low temperature 


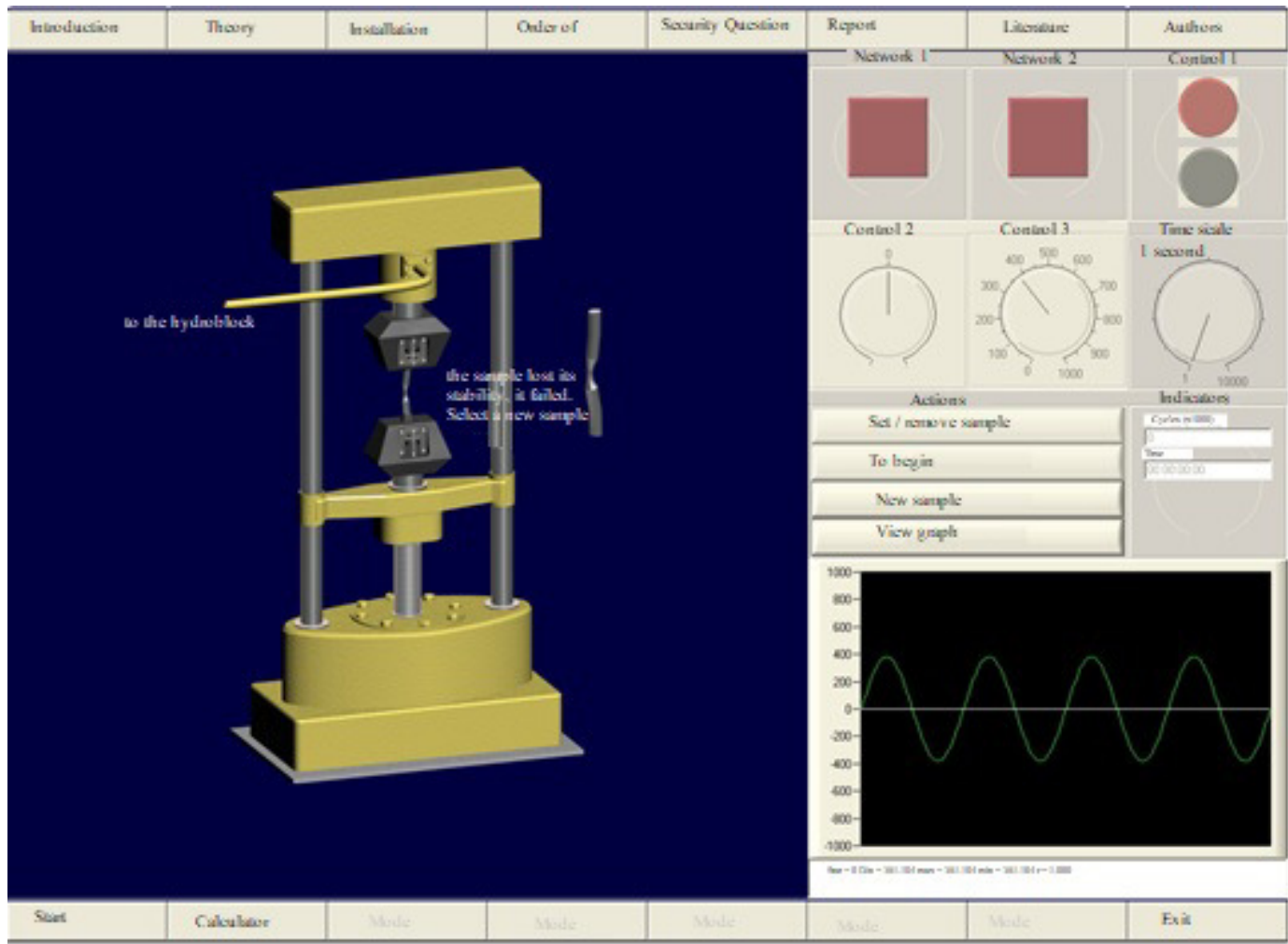

Figure 2.Testing of samples under cyclic tension-compression conditions

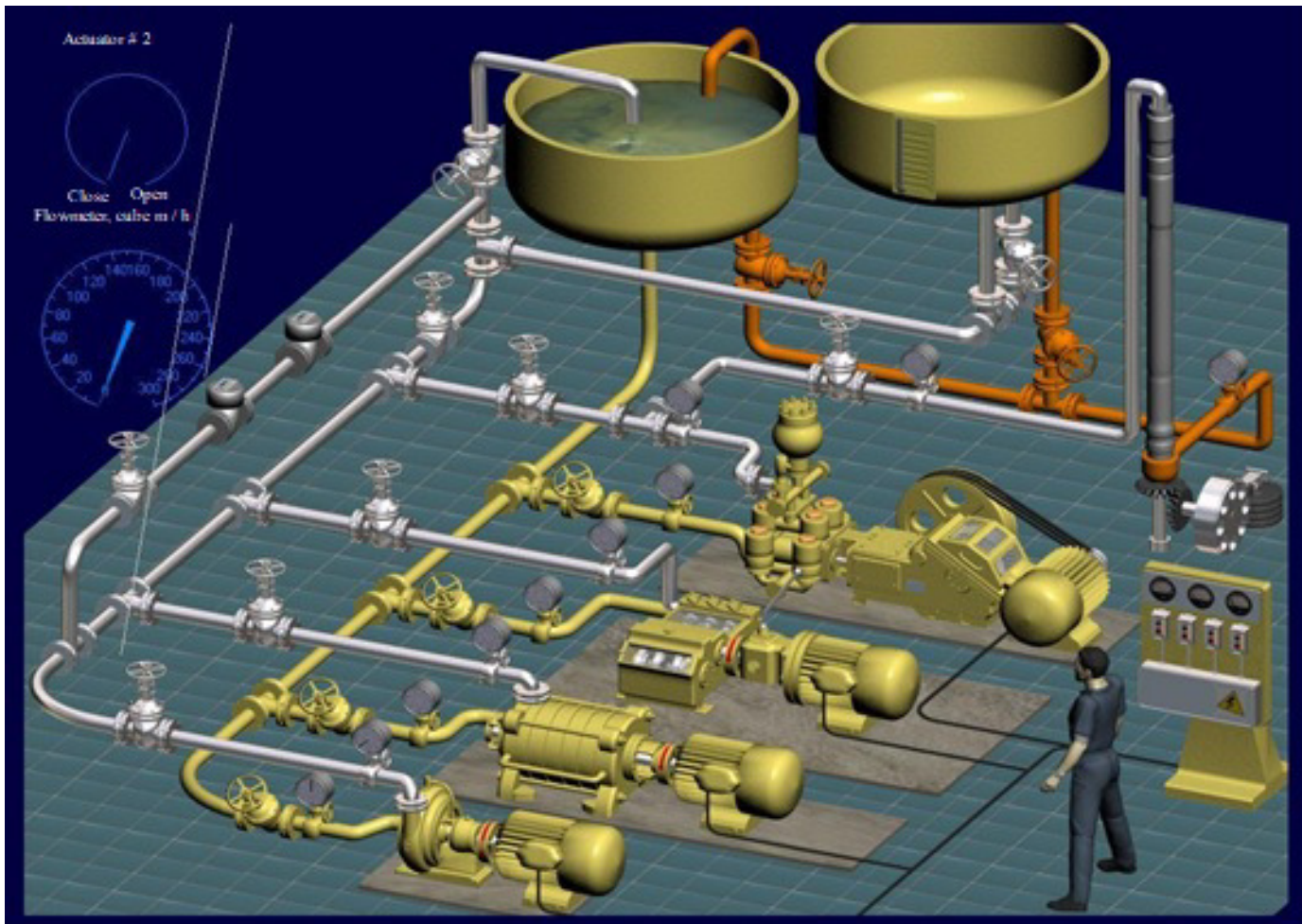

Figure 3. Complex of VLW for the study of the characteristics of pumps 


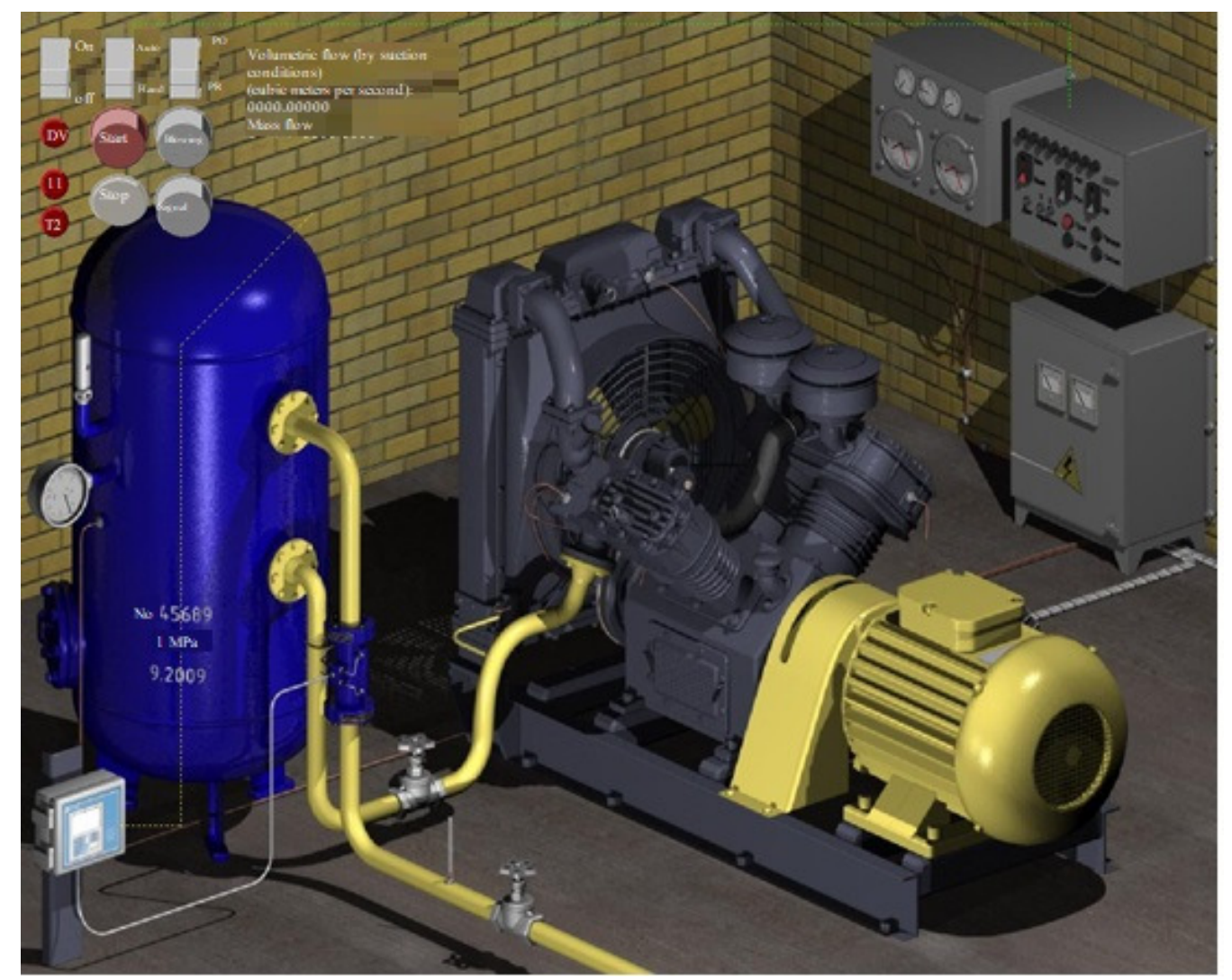

Figure 4. Virtual laboratory work on starting the compressor

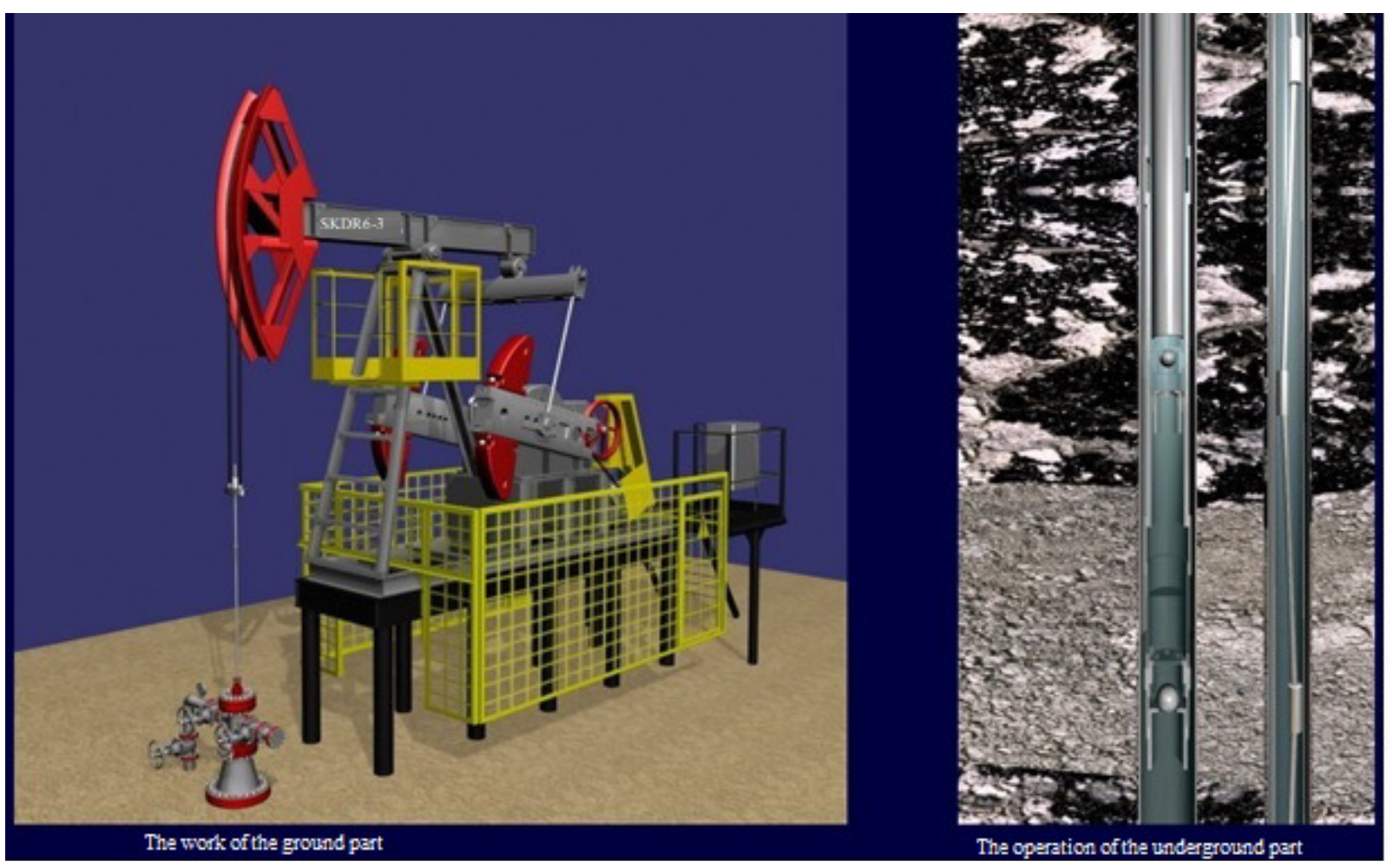

Figure 5. Study of the kinematics of a beam-pumping unit

PERIÓDICO TCHÊ QUÍMICA•www.periodico.tchequimica.com• Vol. 15 N. 30.

•ISSN 1806-0374 (impresso) • ISSN 1806-9827 (CD-ROM) • ISSN 2179-0302 (meio eletrônico)

(c) 2018. Porto Alegre, RS. Brasil

The Periódico Tchê Química (ISSN: 1806-0374; 2179-0302) is an open-access journal since 2004. Journal DOI: 10.52571/PTQ. http://www.tchequimica.com.

This text was introduced in this file in 2021 for compliance reasons.

(c) The Author(s)

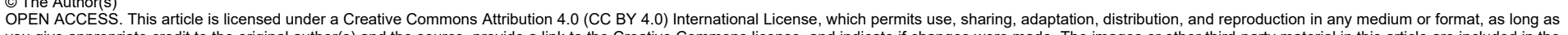
you give appropriate credit to the original author(s) and the source, provide a link to the Creative Commons license, and indicate if changes were made. The images or other third-party material in this article are included in the article 's Creative Commons license unless indicated otherwise in a credit line to the material. If material is not included in the article's Creative Commons license and your intended use is not permitted by statutory regulation or exceeds the permitted use, you will need to obtain permission directly from the copyright holder. To view a copy of this license, visit http://creativecommons.org/licenses/by/4.0/. 